\title{
THE MAIN THESES OF THE ARMENIAN TRANSLATION OF THE DEFINITIONS BY HERMES TRISMEGISTUS
}

\begin{abstract}
Academician Sen Arevshatyan, a great connoisseur of medieval philosophy, enumerates a series of philosophical and theological works, translated in the middle of the $5^{\text {th }}$ century and the beginning of the $6^{\text {th }}$ century, the texts of which have been preserved only in Armenian. Among them one shall cite seven works by Philo of Alexandria and the Definitions by Hermes Trismegistus.

The text of the Hermes' work, which has an international value, was prepared to publication by academician Hacob Manandyan and it was printed in the journal "Banber Matenadarani" ("The Messenger of the Matenadaran"). To prepare the critical text of the work under study H. Manandyan has utilized six manuscripts kept in the Mashtots Matenadaran of Yerevan, the most ancient of which was written in the $13^{\text {th }}$ century, before 1282 .

The Definitions by Hermes Trismegistus were translated into Old Armenian at the second half of the $5^{\text {th }}$ century. Translations made in that period from Greek and Hellenic works have deeply influenced Armenian authors of the Golden Age.

The careful study of this philosophical treaty shows numerous relations between this work and those of the Armenian authors of the $5^{\text {th }}$ century and the following period.

The Armenian translation of Hermes Trismegistus' work proves how much the scientific thought was developed in Armenia still in the $5^{\text {th }}$ century. The fact of the translation of the Definitions by Hermes Trismegistus shows that in the $5^{\text {th }}$ century Neo-Platonism was among the fundamental directions of Armenian philosophy and it is not fortuitous that David the Invincible became the greatest figure of this philosophical direction in Armenia.
\end{abstract}

Keywords: theologian, philosopher, Neo-Platonism, translation, Golden Age, scribe, international, value, oriental, Hellenic.

As a result of the mighty translation activity during the Armenian Golden Age numerous philosophical, theological, literary and historical works were translated from Greek and Syriac into Armenian. They represented the most important manifestations of Antic Greco-Latin, as well as Oriental and Hellenic thought. The originals of a part of these translations were lost, while, fortunately, their translations into Old Armenian Grabar language have been preserved and have now the value of originals, contributing at the same time to the development of Armenian studies. The work Armenian Translations of Ancestors (5 $5^{\text {th }}-13^{\text {th }}$ centuries) by Garegin Zarbhanalian from the Mkhitarist Congrega- 
tion is devoted to Armenian translated literature.

Academician Sen Arevshatyan, a great connoisseur of medieval philosophy, dates back to the $5^{\text {th }}$ century and the beginning of the $6^{\text {th }}$ century the translation of a series of philosophical and theological works which have been preserved only in Armenian. Among them one shall cite seven works by Philo of Alexandria and the Definitions by Hermes Trismegistus (Arevshatyan, 1973, p. 19).

The text of the Hermes' work, which has an international value, was prepared to publication by academician Hacob Manandyan and it was printed in the journal "Banber Matenadarani" ("The Messenger of the Matenadaran"). To prepare the critical text of the work under study, H. Manandyan used six manuscripts kept in the Mashtots Matenadaran of Yerevan, the most ancient of which was written in the $13^{\text {th }}$ century, before 1282 . This manuscript is a "Homilies" written by the scribe Mkhitar Ayrivanetsi in the monastery of Geghard (Catalogue of Manuscripts, 1965, p. 568).

Historian, theologian, theorist of the calendar, poet and pedagogue, Mkhitar Ayrivanetsi gathered in the manuscript he copied an authentic treasury of philosophical and theological works. Among them one can find the works by Dionysius the Areopagite, translated in the $8^{\text {th }}$ century by Stepanos Siunetsi, the Book of Fasting by Basil of Caesarea, the Definitions of Philosophy by David the Invincible, the Introduction by Porphyry, the Art of Grammar by Dionysius of Thrace, the Definitions by Hermes Trismegistus, as well as several works of Aristotle and other important works.
According to the evidence given by Sen Arevshatyan, the Definitions by Hermes Trismegistus were translated into Old Armenian in the second half of the $5^{\text {th }}$ century. Translations made in that period from Greek and Hellenic works deeply influenced the Armenian authors of the Golden Age. "It is a clear and undisputable fact that translations of the works by Dionysius of Thrace, Aphthonius, Theon of Alexandria, Philo of Alexandria and Irenaeus, as well as many other works of the same circle (Definitions by Hermes Trismegistus, The History of Alexander of Macedonia by Pseudo-Callisthenes and so on), were done from the end of the 450-es to the 480-es, or the latest in the middle of the 480-es, and their ideological and lexical influence on the Armenian contemporary authors as Eghishe, David the Grammarian, Movses Khorenatsi and Mambre the Decipherer (supposedly Anonymous), is mentioned by many scholars" (Arevshatyan, 1973, p. 166).

Nowadays famous specialist in Armenian studies Jean-Pierre Mahé, while receiving the spade of membership of the Academy of Inscriptions and Literature of the Paris University La Sorbonne, heartily thanked those Armenian medieval translators who translated into Armenian the works of the Ancient world men of wisdom, a part of which are preserved only thanks to Armenian translations, at the same time expressing his gratitude to Armenian scribes who preserved these works until our days by copying and multiplying them during the following centuries. He praised these translations as the valuable memory of humanity (Mahé, 2002, p. 54).

Mkhitar Ayrivanetsi was among those who preserved the Definitions by Hermes 
Trismegistus, copying the Armenian translation of this work.

According to H. Manandyan, the Definitions which came down to our days under the name of Hermes Trismegistus are a mixture of Neo-Platonism, Oriental mysticism and Egyptian philosophical thought. He insists that the original of the Definitions published by him has not reached our times and adds that "the importance of the Armenian translation is indisputably great as the Greek original is probably lost" (Manandyan, 1956, p. 289). Manandyan explains the meaning of Hermes Trismegistus' name according to the explanation given by the authors of the New Dictionary of the Armenian Language. They think that 'Trismegistus' means 'three times great', famous. Trismegistus has borrowed the name of Hermes, the great Egyptian philosopher. Among Armenians David the Invincible was also called Trismegistus.

According to the evidence given by Kirakos Gandzaketsi, historian of the $13^{\text {th }}$ century, Mkhitar Ayrivanetsi was called Trismegistus as well (Nouveau Dictionnaire de la Langue Arménienne, 1836, p. 662).

The Definitions by Hermes Trismegistus are published in Old Armenian with parallel translation into Russian done by Sen Arevshatyan.

The careful study of this philosophical treaty shows numerous relations between this work and those of the Armenian authors of the $5^{\text {th }}$ century and the following period. Thoughts contained in it can be easily found either in Faithful Speeches by Mesrop Mashtots or in the Refutation of the Sects by Eznik Koghbatsi, the Book of Lamentation by Grigor Narekatsi, the Epistles by Grigor Tathevatsi and in the works of other authors. In the issues of microcosm and macrocosm interrelations the representatives of Armenian official literature are completely corresponding with the theses of the Definitions by Hermes Trismegistus.

The latter says in his Definitions: "God is eternal and uncreated; the man is mortal, always staying a creature" (Manandyan, 1956, p. 299).

We read the same thing said by Eznik: "Everything proceeds from Him (God - A.S.) and $\mathrm{He}$ from nobody. He put the beginning of being to invisible-immaterial and to visiblematerial, to each according to its class" (Koghbatsi, 1970, p. 32).

The theory of the four elements of existence, which comes from Antic philosophy and continues in the Middle Ages, is also found either in the Definitions by Hermes Trismegistus or in the work of Eznik. We read in the Definitions: "The corpse consists from four elements; it is a unique harmonic combination consisting from warmness, coldness, dryness and humidity. From the warmness of fire, the coldness of air, the dryness of earth and the humidity of water" (Manandyan, 1956, p. 299).

Eznik Koghbatsi writes about the same four elements: "And so, the four elements from which this world is made are separately destructive for each other, but combined with their parallels they become useful and advantageous" (Koghbatsi, 1970, p. 33).

It should be noticed that we find the ana$\log$ of the relation between the Heaven and the Earth of the Definitions by Hermes Trismegistus in the song Discussion between the Heaven and the Earth of Nerses Moats, philosopher and poet of the $17^{\text {th }}$ century: "I consider that God is in the Heaven and the Heav- 
en is above the Earth" (Manandyan, 1956, p. 301). Nerses Mokatsi also ends the discussion between Heaven and Earth by their union, because he sees divinity in both. The Heaven bows down before the Earth, because it is the last refuge of the human bodies (Mokatsi, 1975, pp. 42-43).

Specialists know that the famous masterpiece of Grigor Narekatsi, his Book of Lamentation examines the issue of life and death and comes to the conclusion that the human being is mortal by his flesh, but immortal by his wise word.

"And even if as a mortal I shall die

But by the durability of this book I will remain immortal"

$$
\text { (Narekatsi, 1979, p. 527). }
$$

We find the same statement in the Definitions by Hermes Trismegistus: "As to the body human beings are mortal, while as to the word they are immortal" (Manandyan, 1956, p. 302).

Among the authors of the $5^{\text {th }}$ century most of all we can find the influence of Hermes Trismegistus' thoughts in the works of Eghishe. Eghishe considers that the projects of conversion of Yazdegerd II are the result of his ignorance in religious issues. "And all this evil penetrates the human mind because of the lack of instruction. The blind is deprived of the sun's rays, but the ignorance deprives of perfect life. It is better to be blind by eyes, than blind in mind. Just as soul is greater than body, the vision of mind is greater than the vision of body" (Eghishe, 1989, p. 29).

Hermes Trismegistus expresses the same thought in the following way: "Eyes see external things, while mind sees internal ones. Light is where mind is, as the mind is light, and the light is mind" (Manandyan, 1956, p. 307).

In 451 all the Armenian people raised in rebellion for the sake of its national independence and its religious freedom against the conversion project of Yazdegerd II. Eghishe was among the rebels, in the ideological field as well as in the practical one. The following wise formula can be considered as the motto of his history: "As it was said in ancient times, unconscious death is death, conscious death is immortality. Who doesn't know what death is, is afraid of it, but one who knows what death is, doesn't fear it" (Eghishe, 1989, p. 29). We find the same thought in the Book of Lamentation by Grigor Narekatsi:

"As a foreign philosopher

Considers that death is the greatest evil

If it is not really conscious and meaningful,

And I am certifying the same with my words"

(Narekatsi, 1979, p. 330).

Neither Eghishe in the $5^{\text {th }}$ century nor Grigor Narekatsi five centuries later cited the name of Hermes Trismegistus, but they conscientiously confessed that the thought was not theirs and belonged to a philosopher of the ancient times. This philosopher is of course Hermes Trismegistus whose Definitions were known to those two great Armenian authors. We can read in Hermes' work: "Conscious death is immortality, unconscious death is death" (Manandyan, 1956, p. 311). In his Definitions Hermes Trismegistus speaks about the existence of three worlds: "Subsequently, there are three universal worlds: the first is perceived by feelings; the second is understood by mind (i.e. God) and according to the kind of man, and the third one accord- 
ing to the completeness of the whole. All the multitude of things belong to these three worlds: two visible worlds, perceptible and perishable, which are the man, while knowable invisible, i.e. immaterial God who is not visible, but manifests Himself in the visible" (Manandyan, 1956, p. 299).

About this passage Sen Arevshatyan writes: "Using the thesis of Hermes Trismegistus, one of the predecessors of Neo-Platonism, Eghishe says: "There are three worlds: God, the nature and the man. God is the spiritual world, the nature is the sensual world, the man is the spiritual and sensual world" (Arevshatyan, 1973, p. 128).

While studying the issues of good and evil, Eznik Koghbatsi shows relations with the Definitions by Hermes Trismegistus. Eznik is convinced that the man has free thinking and he serves whom he wants. And this free thinking exists not for serving the evil, but for good purposes. "God ... gave him (the man) free thinking to deepen in good things, to be able to do what he wants, and recommended to put free thinking at the service of good things" (Koghbatsi, 1970, pp. 48-49).

In his turn Hermes formulates this thought the following way: "The man has the same power as gods. Only the man is a free creature, only he has power on good and evil" (Manandyan, 1956, p. 307).

The philosophical and theological legacy of Hermes Trismegistus keeps being interesting for orientalists and those who study Antic philosophy. Nowadays, scholars continue to study the treasury of humanity's ancient wisdom. Jean-Pierre Mahé, who knows the Armenian translation of the Definitions by Hermes Trismegistus, has published a series of works of this ancient man of wisdom, com- paring them with Greek and Roman philosophers (Mahé, 1978).

The Armenian translation of Hermes Trismegistus' work proves how much the scientific thought was developed in Armenia still in the $5^{\text {th }}$ century. The fact of the translation of the Definitions by Hermes Trismegistus shows that in the $5^{\text {th }}$ century Neo-Platonism was among the fundamental directions of Armenian philosophy and it is not fortuitous that David the Invincible became the greatest figure of this philosophical direction in Armenia.

\section{REFERENCES}

Arevshatyan, S.S. (1973). Formirovanie filosofskoi nauki v drevnei Armenii ( $V$ $V I v v$.) (The Formation of Philosophical Science in Ancient Armenia (5 $5^{\text {th }}$ $-6^{\text {th }}$ centuries), in Russian). Yerevan.

Cucak d'er'agrac Mashtoci anvan Matenadarani (Catalogue of the Mashtots Matenadaran Manuscripts, in Armenian), h. A. Yerevan.

Eghishe. (1989). Vardani \& hayoc paterazmi masin (About the War of Vardan and the Armenians, in Armenian). T'argmanut'yuny' \& c'anot'agrut'yunnery' (E. Ter-Minasyan Trans. into Modern Armenian and Annot.). Yerevan.

Koghbatsi, E. (1970). Eghc' aghandoc (Refutation of the Sects, in Armenian). T'argmanut'yuny' \& c'anot'agrut'yunnery' (A.A. Abrahamyan, Trans. into Modern Armenian and Annot.). Yerevan.

L'épée de Jean-Pierre Mahé (2002), Paris. 
Mahé, J.-P. (1978). Hermès en Haute-Égypte. Québec.

Manandyan, H. (1956). Hermeay Er'amec'i ar' Askghepios «Sahmanq» (Definitions of Hermes Trismegistus to Asclepius, in Armenian), Banber Matenadarani, No 3. Yerevan.

Mokatsi, N. (1975). Banasteghc'ut'yunner (Poems, in Armenian), (A.G. Dolukhanyan, Ed.). Yerevan.
Narekatsi, G. (1979). Matyan oghbergut'yan (Book of Lamentation, in Armenian). Yerevan.

Nouveau Dictionnaire de la Langue Arménienne (1836). vol. I. Venice.

Zarbhanalyan, G. (1889). Haykakan t'argmanut'iw'nq naxneac (IV-XIII darer) (Armenian Translations of Ancient Authors $\left(5^{\text {th }}-13^{\text {th }}\right.$ centuries $)$, in Armenian). Venice. 